\title{
Promotion Opportunity on Employee Career Change Decision: The Case of a Selected Learning Institution in Kenya
}

\author{
Tuwei J. G. ${ }^{1}$, Matelong K. N. ${ }^{2}$, Boit S. R. ${ }^{1} \&$ Tallam K. Z. ${ }^{2}$ \\ ${ }^{1}$ Department of Marketing \& Management Science, Moi University, Kenya \\ ${ }^{2}$ Department of Quantitative Skills and Entrepreneurial Studies, Moi University, Kenya \\ Corresponding author: Tuwei Jemutai Gloria, School of Business and Economics, Moi University, Eldoret, \\ Kenya. E-mail: tuweigloria2013@gmail.com
}

Received: June 18, 2013

Accepted: July 19, 2013

Online Published: August 20, 2013

doi:10.5539/ijbm.v8n18p53

URL: http://dx.doi.org/10.5539/ijbm.v8n18p53

\begin{abstract}
Employees are a vital competitive tool for organisations; given that success of organisation is determined by its human resources; however career change intention is little known. Knowing the implication of career change in terms of direct cost; replacement, recruitment and selection, temporary staff, management time, or in terms of indirect costs like morale, pressure on remaining staff, cost of learning, organizational can take appropriate measures to reduce career change. Thus, this study examined the effect of promotion opportunity on non teaching staff career change intention in Moi University Eldoret Municipality Kenya. Herzberg's two factor theory guided this study. The research design was a survey. Individual elements were selected using stratified systematic random sampling techniques and the sample size determination was based on Nassiuma method. Data was analysed using both descriptive and inferential statistics. The specific analysis methods in this study included frequencies, percentages, spearman correlation, phi and ordinal regression. The findings indicated that; promotion opportunity had a significant relationship with non teaching staff career change intention. The findings indicated that non teaching staff considered promotion opportunity as the critical indicator of their perception of job satisfaction. This study concludes that promotion opportunity as perceived by non teaching staff had a higher effect on career change intention in Moi University Eldoret Municipality Kenya. Arising from the conclusion of this study, it is recommended that, Moi University ensure that promotion should be based on merit to reduce chances of career change.
\end{abstract}

Keywords: career change intention, promotion opportunity, non teaching staff, Moi University, Kenya

\section{Introduction}

Career change is an issue of concern to institutions given the huge costs related to lost productivity, hiring and training of employees (G. Connolly and M. Connolly, 1991); however, career change has received little attention in the learning institution literature. Promotion opportunity can be used to predict career change. Milkovich and Boudreua (1997) in a study of Singapore accountants found that promotion opportunity as the main predictor of career change. Moreover, human resources are the most valuable assets in organizations and when they quit, it is an indication that the organization is in trouble (Clark, 2001; Kristensen and Wastergard, 2004). Management need to motivate and reward high performing employees to prevent them from quitting. Knowing the factors contributing to the employees satisfaction; organization can plan and take appropriate step to increase positive behaviour among employees (Seta et al., 2000). Given that an understanding of career change can be a major tool in shaping this institution. Failure to address the influence of promotion opportunity on non teaching staff career change in Moi University Eldoret Kenya may affect their performance which could have resulted in increased employee productivity, motivation and reduced career change. Thus the research question can be formulated as follows: Which indicators of promotion opportunity are adopted by Moi University Eldoret, Kenya and how do they influence career change intention among the non teaching staff?

\subsection{Hypothesis}

Variables that indicated promotion opportunity included; plenty of promotion opportunities, chance of promotion, wish to be promoted, procedures and steps in promotions and number of times promoted. Promotion opportunity included; plenty of promotion opportunities, chance of promotion, wish to be promoted, procedures and steps in promotions and number of times promoted. While career change intention included; not considering 
and considering making a career change. Therefore, this research tests the effect of promotion opportunity on non teaching staff career change intention in Moi University Eldoret Municipality Kenya.

Therefore, the hypothesis for this study was formulated as follows:

$\mathbf{H}_{\mathbf{0 1 a}}$ There is no statistically significant relationship between promotion opportunity and non teaching staff not considering making a career change.

$\mathbf{H}_{\mathbf{0 1 b}}$ There is no statistically significant relationship between promotion opportunity and non teaching staff considering making a career change.

\section{Literature Review}

\subsection{Promotion Opportunity and Career Change}

Promotion is the advancement of an employee's rank or position in an organizational hierarchy system (Goblar et. al., 2002). He further alludes that, promotion may be an employee's reward for good performance that is, positive appraisal. Before a company promotes an employee to a particular position it ensures that the person is able to handle the added responsibilities by screening the employee with interviews and tests and giving them training or on-the job experience. A promotion can involve advancement in terms of designation, salary and benefits, and in some organizations the type of job activities may change a great deal (Kalesh et. al., 2007). Empirically, promotion in a business organization is a practice for recognizing and rewarding employees' effort and contribution to the group. It is usually symbolized with a change of job and title. It can be attached with an increase in pay, power, and responsibility. Or, it can also include an increase in freedom or independence, or a decrease in danger or discomfort. It may mean less inconvenience in terms of hours or location for some employees (Kalesh et. al., 2007). Based on the above discussion, employees often feel satisfied with these incentives and stimulated to perform better in the new job. They are motivated to increase their knowledge or skill and to gear for higher levels of productivity. With better jobs, employees may decline any opportunities at other companies. Hence, promotions can increase employees' loyalty to the company and reduce career change intention at lower levels. An employee's opportunities for promotion are also likely to exert an influence on job satisfaction (Landy, 1989; Larwood, 1984; Moorhead \& Griffen, 1992; Vecchio, 1988). Robbins (1998) maintains that promotions provide opportunities for personal growth, increased responsibility, and increased social status (Robbins \& Judge, 2007). Drafke and Kossen (2002) was of the opinion that many workers experience satisfaction when they believe that their future prospects are bright and good and this may according to Bull (2005) "translate into opportunities for advancement and growth in their current workplace, or enhance the chance of finding alternative employment". It was stressed further that if people feel they have limited opportunities or chance for career advancement in any organization, their job satisfaction may decrease which consequently may lead to career change. According to McCormick and Ilgen (1985), employees' satisfaction with promotional opportunities will depend on a number of factors, including the probability that employees will be promoted, as well as the basis and the fairness of such promotions. Moreover, not all employees wish to be promoted. The reason therefore is related to the fact that promotion entails greater responsibility and tasks of a more complex nature, for which the individuals may consider themselves unprepared. If employees perceive the promotion policy as unfair, but do not desire to be promoted, they may still be satisfied. Nonetheless, opportunities for promotion appear to have a significant positive correlation with career intention (Tolbert \& Moen, 1998). Promotions may take a variety of different forms and are generally accompanied by different rewards (Luthans, 1992). Equally, promotional opportunities therefore have differential effects on career intention, and it is essential that this be taken into account in cases where promotion policies are designed to enhance employee satisfaction. It has been shown that employees are more committed to their jobs when they believe that the organization they work for pursues a promotion from within policy. If they believe a promotion from within policy is not exercised, they would feel less uncertain regarding the future of their career in the organization, becoming more motivated to consider career change. Overall, employees often feel satisfied with these incentives and stimulated to perform better in the new job. They are motivated to increase their knowledge or skill and to gear for higher levels of productivity. With better jobs, employees may decline any opportunities at other organizations. Hence, promotions can increase employees' loyalty to the organization and reduce intention to change careers at lower level (Gaertner \& Nollen, 1989).

\subsection{Conceptual Framework}

It is the assumptions of this study that, career change occurs through a process that combines Promotion opportunity indicators that includes; plenty of promotion opportunities, chance of promotion, wish to be promoted, procedures and steps in promotions and number of times promoted. Career change intention included not considering making a career change and considering making a career change. Promotion opportunity was 
considered as the independent variable in this study, while career change was considered as the dependent variable. Moi University integrates promotion opportunity in such a way that they influence career change as reflected in the dependent variable measures; considering making and not considering making a career change. The conceptual framework in this study as presented in Figure 1 was based on Herzberg's two factor theory by Frederick Herzberg 1959.

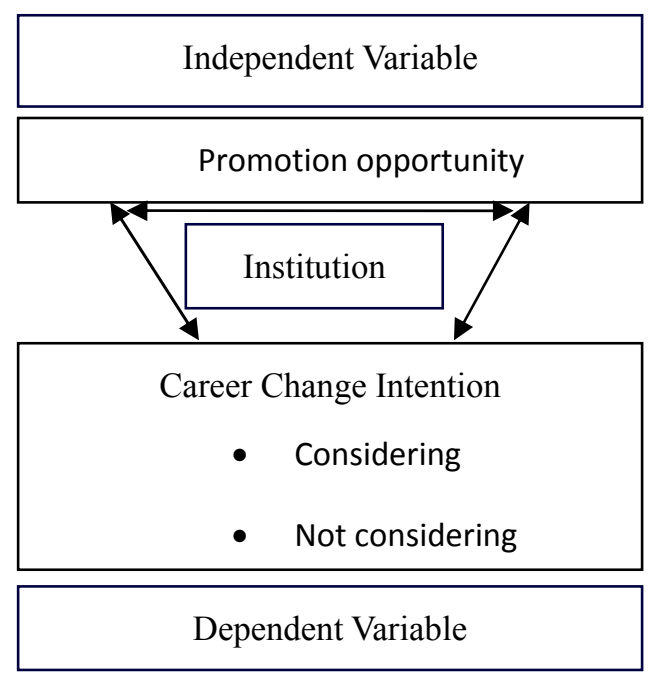

Figure 1. Conceptual framework of promotion opportunity on non teaching staff career change intention

\section{Materials and Methods}

The study adopted a survey strategy in which the idea of a survey is that the researcher obtains the same kind of data from a large group of people or events in a standardised and systematic way and that a researcher then looks for patterns in the data that can be generalised to a large population than the group targeted (Martyn, 2010). Survey is a common strategy in business and management research. Survey facilitates collection and analysis of a given set of characteristics in a population and allows collection of a large amount of data from a population in a highly economical way. Surveys involve asking questions, interviewing, which form the basis for deriving information (Oates, 2010). Surveys are enumerative and not manipulative. Complete enumeration is usually very costly; however under certain conditions complete enumeration may be necessary. Survey strategy allows a researcher to collect qualitative data which can be analyzed quantitatively using descriptive and inferential statistics (Saunders et al., 2009). In addition, data collected using a survey strategy can be used to suggest possible reasons for particular relationships between variables. Survey design is perceived to be authoritative by people in general and it is easily understood, and can therefore result in valuable findings if correct procedures are followed. Independent variable in the study was promotion opportunity measured on ordinal scale. The dependent variable was career change which included not considering making and considering making a career change measured on ordinal scale.

The sample size determination, for this study was based on Nassiuma, 2000, formula for calculating the minimum sample size required. The non teaching staffs who participated in the study had to have been working in the school for more than six months. An investigation was first done to identify the total number of non teaching staffs in each school. Schools were geographically concentrated in different locations of Eldoret municipality. Sample selection for this study was achieved using stratified and systematic random sampling as mentioned above. The study area was divided into 13 Schools (Aerospace Science, Arts and Social Sciences, Business and Economics, Dentistry, Education, Engineering, Human Resource Development, Biological and Physical Sciences, Information Science, Law, Medicine, Nursing and Public Health). The stratification was based on the Schools. The sample size for the respective school was based on the proportionate population of non teaching staffs in each School. The individual non teaching staff was selected from the population using a 1-in 3 systematic sample. The first non teaching staff was selected with a random start. However, the non teaching staffs were required to have worked in the university for more than six months; the next non teaching staff was selected by walking into offices to select the next $3^{\text {rd }}$ non teaching staff. This was carried out by the researcher with the aid of a trained research 
assistant. This was done until all the non teaching staffs determined for the study was selected. Systematic sampling method was used because it was found to be easier to perform, given that it is less subject to selection errors. It also provides greater information per unit cost as compared to simple random sampling. Stratified sampling is widely used because it simplifies the sample selection process. The sampling methods used in this study were based on the sampling frame. The sampling methods used in this study comprised stratified systematic random sampling. In survey based studies inferences are made from the sample about the population. The sampling methods used in this study comprised stratified systematic random sampling. In survey based studies inferences are made from the sample about the population. Data was collected through questionnaires measured using a five-point likert-type response scale, anchored at 1 Strongly Agree through 5 Strongly Disagree. The researcher with the aid of a research assistant administered 158 questionnaires, 6 were dropped due to non teaching staff's inability to fill the questions. The size of the sample stands at 152 with a response rate of (96\%) as indicated in Table 1.

Table 1. Questionnaires administered and returned

\begin{tabular}{lcc}
\hline Response & No. of questionnaires & Percentage $(\%)$ \\
\hline Effective questionnaires & 152 & $96 \%$ \\
Returned but defective & 6 & $4 \%$ \\
Total & 158 & $100 \%$ \\
\hline
\end{tabular}

This study ensured validity through content validity; through a review by an expert in this field, and a review of literature and previous research. This study ensured reliability through Cronbach's alpha reliability tests as presented in Table 1. The Cronbach's Alpha coefficient for the items under scrutiny was 0.821 and 0.844 respectively, as shown in Table 2 indicating that the overall reliability was excellent. Alpha value of 0.70 or above is considered to demonstrate reliability (Muijs, 2008; Sekaran and Bougie, 2010). As indicated in Table 1 all the items were reliable since all the items included were reliable and measured Cronbach's alpha greater than 0.70 , which indicated the good reliability of the instruments used for measurement. The measurement levels determined analysis methods for this study (Muijs, 2008; Sekaran and Bougie, 2010; Pallant, 2001). Data analysis aimed at searching and identifying patterns of relationships that existed among the independent and dependent variables in this study. Data collected in this study was analysed by descriptive and inferential statistics where appropriate. Descriptive analysis was by frequencies and percentages. While, inferential statistics was by Spearman's rho correlation to establish the relationship between the study variables; ordinal regression analysis to estimate the magnitude of the effect of the independent variable on the dependent variable; Chi-square to test the study hypothesis and Phi to measure the strength of the relationship between the study variables.

Table 2. Cronbach's Alpha reliability tests results

\begin{tabular}{cccc}
\hline Constructs & Cronbach's Alpha & Number of Items & Reliability Status \\
\hline Promotion opportunity & 0.821 & 6 & Reliable \\
Career change & 0.844 & 2 & Reliable \\
\hline
\end{tabular}

\section{Results and Discussion}

The findings of this study are presented on the basis of the study objective: To examine the effect of promotion opportunity on career change intention of non teaching staff.

\section{Effect of Promotion Opportunity on Career Change Intention of Non Teaching Staff}

The effect of promotion opportunity on career change intention of non teaching staff was based on the study objective. This assisted in answering whether the contents of promotion opportunity had a relationship with non teaching staff career change intention. Information in this section was based on promotion opportunity indicators; promotion opportunities, chance of promotion, procedures taken in promotions and several times the non teaching staff had been promoted measured on an ordinal scale. The dependent variable was non teaching staff career change intention. 


\section{Frequencies of Promotion Opportunity In Relation To Job Satisfaction}

The frequencies of promotion opportunity in relation to job satisfaction as perceived by the non teaching staff are presented in Table 3.

Table 3. Frequencies of promotion opportunity in relation to job satisfaction

\begin{tabular}{|c|c|c|}
\hline Indicators of promotion opportunity Rank & $\mathrm{F}$ & $\%$ \\
\hline \multicolumn{3}{|l|}{ I have opportunities for promotion } \\
\hline Agree & 54 & 36 \\
\hline Neutral & 28 & 18 \\
\hline Disagree & 70 & 46 \\
\hline Total & 152 & 100 \\
\hline \multicolumn{3}{|l|}{ I would wish to be promoted } \\
\hline Agree & 148 & 98 \\
\hline Neutral & 2 & 1 \\
\hline Disagree & 2 & 1 \\
\hline Total & 152 & 100 \\
\hline \multicolumn{3}{|c|}{ I am satisfied with the steps in giving promotions } \\
\hline Agree & 46 & 30 \\
\hline Neutral & 20 & 13 \\
\hline Disagree & 86 & 57 \\
\hline Total & 152 & 100 \\
\hline \multicolumn{3}{|l|}{ I have been in the same position for a long time } \\
\hline Agree & 96 & 63 \\
\hline Neutral & 16 & 11 \\
\hline Disagree & 40 & 26 \\
\hline Total & 152 & 100 \\
\hline \multicolumn{3}{|l|}{ I have been promoted several times } \\
\hline Agree & 12 & 8 \\
\hline Neutral & 14 & 9 \\
\hline Disagree & 126 & 83 \\
\hline Total & 152 & 100 \\
\hline
\end{tabular}

The study findings indicate firstly, most $(70,46 \%)$ respondents perceived negatively opportunities for promotion as an indicator of job satisfaction, while $(54,36 \%)$ were positive in perceiving promotion opportunities to indicate job satisfaction. This could imply that non teaching staff did not think that the University offered ample opportunities for promotions. This contradicts the findings of Tolbert and Moen, (1998) which stated that opportunities for promotion appear to have a significant positive correlation with job satisfaction. Secondly, the study findings indicate majority of the $(148,98 \%)$ respondents perceived positively wishing to be promoted as an indicator of job satisfaction, surprisingly $(2,1 \%)$ were negative. This could imply that majority of the non teaching staff wished to be promoted to the next level in their respective jobs. Thirdly, most $(86,57 \%)$ of the respondents perceived negatively steps and procedures taken in giving promotion not to indicate job satisfaction, while (46, $30 \%$ ) were positive. This could imply that non teaching staff perceived the university's steps in giving promotions not in proper standard. Fourthly, majority of the respondents $(96,63 \%)$ perceived positively they had been in the same position since employed as an indicator of job satisfaction, while $(40,26 \%)$ were negative on the position they are in at the moment. This could imply that most of the non teaching staff had been in the same position since 
the time of employment. Lastly, most of the respondents $(126,83 \%)$ were negative and perceived times promoted not to indicate job satisfaction, while $(12,8 \%)$ were positive that they had been promoted several times since employed. This could imply that most non teaching staff had not been promoted since they were employed at the university. From the study findings, it is clear that majority of the non teaching staff were not of the view that promotion opportunity indicated job satisfaction.

\section{Relationship between Promotion Opportunity and Non Teaching Staff Career Change Intention}

This study shows the relationship between promotion opportunity and non teaching staff career change intention. The Spearman's rho correlation coefficient between promotion opportunity and non teaching staff career change intention is presented in Table 4.

Table 4. Spearman's rho correlation coefficient of promotion opportunity and non teaching staff career change intention

\begin{tabular}{|c|c|c|}
\hline Promotion opportunity indicators & Not considering making career change & Considering making Career change \\
\hline \multicolumn{3}{|l|}{ Opportunities for promotion } \\
\hline Correlation & 0.061 & -0.053 \\
\hline P-value & 0.465 & 0.515 \\
\hline \multicolumn{3}{|l|}{ Wish to be promoted } \\
\hline Correlation & $-0.264 * *$ & $0.331 * *$ \\
\hline P-value & 0.001 & 0.000 \\
\hline \multicolumn{3}{|l|}{ Procedures in promotions } \\
\hline Correlation & 0.060 & -0.069 \\
\hline P-value & 0.465 & 0.395 \\
\hline \multicolumn{3}{|l|}{ Time in the same position } \\
\hline Correlation & -0.067 & 0.070 \\
\hline P-value & 0.409 & 0.395 \\
\hline \multicolumn{3}{|l|}{ Number of times promoted } \\
\hline Correlation & 0.111 & -0.146 \\
\hline P-value & 0.173 & 0.073 \\
\hline
\end{tabular}

** Denotes Correlation is significant at the 0.01 level (2-tailed); * Denotes Correlation is significant at the 0.05 level (2-tailed).

The study findings indicate that promotion opportunities indicators; procedures and steps taken in giving promotions, had no statistical significant relationship $(\mathrm{p}>0.05)$ with career change intention. This study suggests that promotion opportunity, procedures and steps taken in giving promotions had no statistical significant relationship with career change intention. Equally, the study findings indicate that promotion opportunities indicators; time taken to be promoted and number of times promoted had no statistical significant relationship $(\mathrm{p}>0.05)$ with career change intention. This study suggests that time taken for one to be promoted and number of times promoted had no statistical significant relationship with career change intention. In addition, non teaching staff who wished to be promoted had a negative statistical significant relationship $\left(r_{s}=-0.264, * * p<0.05\right)$ with non teaching staff not considering making a career change. This could imply that the more the non teaching staffs wish to be promoted, the lower the possibilities of not considering making a career change. The chances of the non teaching staffs not considering making a career change would be less due to the higher wish by the non teaching staffs to be promoted. On the other hand, non teaching staff who wished to be promoted had a positive statistical significant relationship $\left(\mathrm{r}_{\mathrm{s}}=0.331,{ }^{* *} \mathrm{p}<0.05\right)$ with non teaching staff considering making a career change. The findings imply that as the non teaching staff increase their desire to be promoted, the higher the possibilities of considering making a career change. This could mean that if their wish does not become reality, then they would consider moving to other jobs where they would not just wish to be promoted but instead they would actually be given the promotions deserved.

\section{Ordinal Regression Analysis of Non Teaching Staff Career Change Intention with Promotion Opportunity}

The study findings indicate opportunity for promotion had a negative effect $(\beta=-1.606 \mathrm{p}<0.05)$ on non teaching staff not considering making a career change. This could imply that even though non teaching staffs are not considering making career change, promotion opportunity is a key issue for instance most non teaching staff who had worked in the university for a long time would expect to be promoted. Thus the university should promote employees basing on qualification and years of experience being considered to reduce career change. 
The ordinal regression analysis between non teaching staff not considering making a career change with promotion opportunity is presented in Table 5 .

Table 5. Ordinal regression of non teaching staff not considering making a career change with promotion opportunity

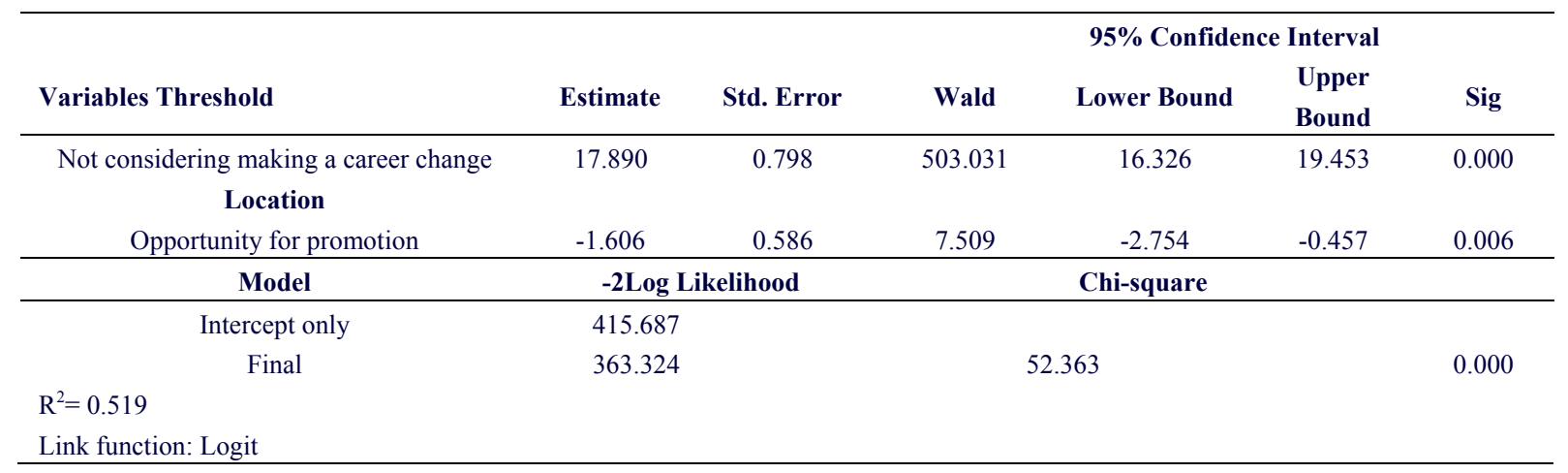

\section{Hypothesis Testing: $\mathrm{H}_{01 a}$}

$\mathbf{H}_{\mathbf{0 1 a}}$ : There is no statistically significant relationship between promotion opportunity and non teaching staff not considering making a career change

In order to analyze this hypothesis, Table 5 , indicates that, $-2 \log$ likelihood of the model with only intercept is 415.687 while the $-2 \log$ likelihood of the model with intercept with independent variables final is 363.324 . That is the difference (Chi-square statistics) is $415.687-363.324=52.363$ which is significant at $p<0.05$ shows there is an association between promotion opportunity and non teaching staff not considering making a career change.

$$
\begin{aligned}
\text { phi } & =\frac{52.363}{152} \\
= & 0.344 \\
& =\sqrt{0.344} \\
& =0.587
\end{aligned}
$$

Equally, the Phi effect size of (0.59), refer to Table 7 shows that the relationship between promotion opportunity and not considering making a career change is strong. In addition the $\mathrm{R}^{2}$ value of 0.519 indicates that $(52 \%)$ of the variance is statistically significant in explaining career change intention using the predictor. The Chi-square value which is significant at $(\mathrm{p}<0.05)$ level shows that promotion opportunity plays a significant role in influencing non teaching staff career change intention. The results also show that the lower and upper bound for both dependent and independent variables does not contain a zero value. Hence the results indicate confidence (95\%) that there is a significant change between promotion opportunity and career change intention. Thus, the null hypothesis is rejected and the alternative hypothesis is accepted indicating that there is an association between promotion opportunity and not considering making a career change. 
Table 6. Ordinal regression of non teaching staff considering making a career change with promotion opportunity

\begin{tabular}{|c|c|c|c|c|c|c|}
\hline \multirow[b]{2}{*}{ Variables Threshold } & \multirow[b]{2}{*}{ Estimate } & \multirow[b]{2}{*}{$\begin{array}{c}\text { Std. } \\
\text { Error }\end{array}$} & \multicolumn{4}{|c|}{ 95\% Confidence Interval } \\
\hline & & & Wald & Lower Bound & $\begin{array}{l}\text { Upper } \\
\text { Bound }\end{array}$ & Sig \\
\hline Considering making a career change & -6.872 & 2.174 & 9.989 & -11.134 & -2.611 & 0.002 \\
\hline \multicolumn{7}{|l|}{ Location } \\
\hline Steps in promotion & -1.875 & 0.727 & 6.657 & -3.299 & -0.451 & 0.010 \\
\hline Same position & -1.724 & 0.749 & 5.302 & -3.191 & -0.065 & 0.041 \\
\hline Model & $-2 \log$ Likeli & & Chi-squar & & & \\
\hline Intercept only & 373.629 & & & & & \\
\hline Final & 325.274 & & 48.354 & & & 0.000 \\
\hline \multicolumn{7}{|l|}{$\mathrm{R}^{2}=0.576$} \\
\hline Link function: Logit & & & & & & \\
\hline
\end{tabular}

Table 6 indicates the steps taken in giving promotions had a negative effect $(\beta=-1.875 p<0.05)$ on non teaching staff considering making a career change. This finding compares well with those of Gaertner and Nollen, (1989) who found that if employees believe a promotion from within policy is not exercised, they would feel less uncertain regarding the future of their career in the organization, becoming more motivated to consider career change. This could mean that the non teaching staffs were not satisfied with the procedures the university uses in giving promotions hence considering making a career change. Thus the university should be fair in giving promotions for example, not favouring an individual for who he or she is, but promote basing it on merit so as to avoid career change. Further, the study findings indicate that non teaching staff being in the same position for a long time had a negative effect $(\beta=-1.724 \mathrm{p}<0.05)$ on considering making a career change. This could imply that one being in the same position tends to affect ones performance at the work place resulting to absenteeism, low self esteem. This may force an employee to search for well paying jobs in other organisation. The university should ensure longer working employees be considered for promotion to minimize career change.

\section{Hypothesis Testing: $\mathrm{H}_{01 b}$}

$\mathbf{H}_{\mathbf{0 1 b}}$ : There is no statistically significant relationship between promotion opportunity and non teaching staff considering making a career change

In order to analyze this hypothesis, Table 6 , indicates that, -2log likelihood of the model with only intercept is 373.629 while the $-2 \log$ likelihood of the model with intercept with independent variables final is 325.274 . That is the difference (Chi-square statistics) is $373.629-325.274=48.354$ which is significant at $\mathrm{p}<0.05$ shows there is an association between promotion opportunity and non teaching staff considering making a career change.

$$
\begin{gathered}
\text { phi }=\frac{48.354}{152} \\
=0.318 \\
=\sqrt{0.318} \\
=0.562
\end{gathered}
$$

Table 7. Cut off points to measure the strength of the relationship

\begin{tabular}{lc}
\hline Effect Size & Strength of Relationship \\
\hline$<0.1$ & Weak \\
$<0.3$ & Modest \\
$<0.5$ & Moderate \\
$<0.8$ & Strong \\
$>0.8$ & Very Strong \\
\hline
\end{tabular}

Source: Muijs Daniel (2008). 
Equally, the Phi effect size of (0.56), refer to Table 7 shows that the relationship between promotion opportunity and considering making a career change is strong. In addition the $\mathrm{R}^{2}$ value of 0.576 indicates that $(58 \%)$ of the variance is statistically significant in explaining career change intention using the predictor. The Chi-square value which is significant at $(\mathrm{p}<0.05)$ level shows that promotion opportunity plays a significant role in influencing non teaching staff career change intention. The results also show that the lower and upper bound for both dependent and independent variables does not contain a zero value. Hence the results indicate confidence (95\%) that there is a significant change between promotion opportunity and career change intention. Thus, the null hypothesis is rejected and the alternative hypothesis is accepted indicating that there is an association between promotion opportunity and considering making a career change.

\section{Conclusion}

In conclusion, the purpose of this study was to identify the effect of promotion opportunity on non teaching staff career change intention. Besides that, this study presents solutions to some of the issues regarding promotion opportunity and how to reduce career change intentions among the non teaching staff of Moi University. This was important since satisfaction with one's job can affect not only motivation at work but also career decisions, in that if people are dissatisfied, they tend to consider changing careers and look for other jobs. Those who work in a profession that is extremely demanding and sometimes unpredictable can be susceptible to feelings of uncertainty and reduced job satisfaction. The study findings indicate that satisfaction exceeded expectations for promotion opportunity surveyed in Moi University. Thus Moi University needs to improve on the aspect of promotion. The study shows promotion opportunity as a critical indicator of job satisfaction as perceived by non teaching staffs in Moi University Eldoret Municipality, Kenya. Thus promotion opportunity needs to be critically analyzed so as to improve non teaching staffs' job satisfaction and as a result reduce chances of employee career change.

\section{Recommendations}

1) The University should ensure that there are ample opportunities for promotion and accord equal chances to every non teaching staff for promotions and device a method of promoting employees say after every ten years. This will give equal opportunities to all and avoid biasness and corruption.

2) In addition the University should ensure that they adopt a standardized procedure that is acceptable by all in giving promotions and ensure that the employees do not stay in the same position for a long time without being promoted.

\section{References}

Bull, I. H. F. (2005). The Relationship Between Job Satisfaction and Organizational Commitment amongst High Engagement. Journal of Nursing Administration, 37, 77-84.

Clark, A. E. (2001).What really matters in a job? Hedonic Measurement Using Quit Data. Labour Economics, 8 , 223-242.

Connolly, K. G., \& Connolly, P. M. (1991). Competing for Employees: Proven Marketing Strategies for Hiring and Keeping Exceptional People. Toronto: Lexington Books.

Gaertner, K. N., \& Nollen, S. D. (1989). Career Experiences, Perceptions of Employment Practices.

Goblar, P. A., Warnich, S., Carrel, M. R., Elbert, N. F., \& Hatfield, R. D. (2002). Human Resources Management in South Africa (2nd ed.). London: Thomson Learning.

Kalesh, B. J., Curley, M., \& Stefanov, S. (2007). An Intervention to enhance Nursing Staff Teamwork and School Teachers in disadvantaged areas in the Western Cape University of the Western Cape.

Kristensen, N., \& Westergard, N. N. (2004). Does low Job Satisfaction lead to Job Mobility? IZA Discussion Paper No.1026. Labour Markets. London, Routledge: McGraw-Hill.

Landy, F. J. (1989). Psychology of Work Behavior (4th ed.). Belmont: Wadsworth.

Larwood, L. (1984). Organizational Behavior and Management. Boston: Kent Publishing Company.

Luthans, F. (1992). Organizational Behavior (6th ed.). New York: McGraw-Hill.

Martyn, D. (2010). The Good Research Guide for Small Scale Social Research Projects (4th ed.). McGraw-Hill.

McCormick, E. J., \& Ilgen, D. R. (1985). Industrial and Organizational Psychology (8th ed.). London: Allen

Milkovich, G. T., \& Boudreau, J. W. (1997). Human Resource Management (8th ed.). New York: Irwin McGraw-Hill. 
Moorhead, G., \& Griffen, R. W. (1992). Organizational Behavior (3rd ed.). Boston: Houghton Mifflin Company.

Nassiuma, D. (2000). Survey Sampling: Theory and Methods. Nairobi University Press.

Oates, B. J. (2010). Researching Information Systems and Computing. Sage Publications.

Pallant, J. (2001). SPSS Survival Manual. Buckingham: Open University Press.

Robbins, S. P., \& Judge, T. A. (2007). Organizational Behaviour (12th ed.). New Jersey: Pearson Education, Inc.

Saunders, M., Lewis, P., \& Thornhill, A. (2009). Research Methods for Business Students (5th ed).. Prentice Hall.

Sekaran, U., \& Bougie, R. (2010). Research Methods for Small Business. A Skill Building Approach.

Seta, C. E., Paulus, P. B., \& Baron, R. A. (2000). Effective Human Resource Relations: A Guide to People at Work (4th ed.). United State of America: Allyn and Bacon.

Tolbert, P. S., \& Moen, P. (1998). Men and Women Definition of "Good” Jobs. Work and Occupations, 25(2), 168-195.

Unwin. \& Vecchio, R. P. (1988). Organizational Behavior. New York: Dryden Press.

\section{Copyrights}

Copyright for this article is retained by the author(s), with first publication rights granted to the journal.

This is an open-access article distributed under the terms and conditions of the Creative Commons Attribution license (http://creativecommons.org/licenses/by/3.0/). 